\title{
Incidence and population of plant parasitic nematodes in green amaranth (Amaranthus hybridus L.) (Caryophyllales: Amaranthaceae) from three selected areas in Dutsin-Ma Town, Katsina State, Nigeria
}

\section{Jibia Abdulhadi Bawa' ${ }^{1 *}$, Zurmi Rabi’u Sani², Iliya Mohammed ${ }^{3}$, Sani Garba Muhammad ${ }^{4}$ and Sanusi Liadi ${ }^{5}$}

${ }^{1}$ Department of Biological Sciences, Faculty of Science, Federal University Dutsinma, Katsina State, Nigeria.*Email: bawa51@yahoo.com, abawa@fudutsinma.edu.ng. ${ }^{2}$ Department of Biological Sciences, Faculty of Science, Federal University Gusau, Zamfara State, Nigeria

${ }^{4}$ Zamfara State College of Education Maru, Zamfara State, Nigeria.

${ }^{5}$ Biology Department, School of Sciences, Isa Kaita College of Education, Dutsin-Ma, Katsina State, Nigeria.

\begin{abstract}
An experiment was conducted in the Department of Biological Sciences, Federal University Dutsinma, Katsina State Nigeria, between May to August, 2016. A survey was carried out from three farm areas around Dutsin-Ma Metropolis to investigate and determine the incidence and population of plant parasitic nematodes of green amaranth (Amaranthus hybridus L.). A total of 240 soil root samples from an infested $A$. hybridus were taken $10 \mathrm{~cm}$ deep from the rhizosphere of the green amaranth plant. The samples were extracted using Cobb-Seiving and Decanting Method. From the supernatants residue, a total of nine genera of plant parasitic nematodes were identified, with 6 genera in Farm 1, 8 genera in Farm 2, and 5 genera in Farm 3. The genera Meloidogyne (23.33\%), has the highest incidence followed by Xiphinema (14.58\%), Pratylenchus (13.33\%), Heterodera (10.83\%), Paratrichodorus (10.83\%), Aphelenchoides (9.16\%), Helicotylenchus (8.33\%), Tylenchorhychus (7.92\%) and Longidorus (7.08\%). Data on incidence from root galling was also taken from the examined samples, with Farm 2 having highest value for moderate root gall damage. It has been deduced from the result that most of the plants with high parasitic load of the nematodes exhibit root gall, chlorotic and perforated leaves, darker weak stems, stunted growth and poor flowering. This results shows that there is a widespread distribution of plant parasitic nematodes against the A. hybridus plants in the surveyed areas (Farm 1, 2 and 3). The presence of these parasitic nematodes, even at low populations in the soil is not significant $(\mathrm{P}>0.05)$ in comparison with all the root samples from the three selected farms $(\mathrm{F}=0.12, \mathrm{P}=0.8803)$. The parasitic nematode population built up could eventually result in great reduction of the crop yield. Establishing efficient research control on the damaging potentials of these parasitic nematodes as against this
\end{abstract}

Received

November 11, 2016

Accepted

December 20, 2016

Released

December 31, 2016

Open Acess Full Text Article

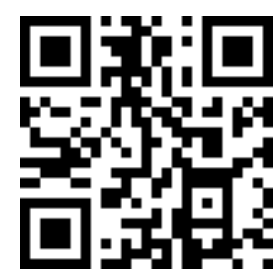

ORCID

(1) 0000-0002-3487-1440 Jibia Abdulhadi Bawa (D) 0000-0001-6466-2626 Zurmi Rabi'u Sani (D) 0000-0001-5092-9596 Iliya Mohammed

(1) $0000-0002-3624-2752$ Sani Garba Muhammad (D) 0000-0002-1100-3499 Sanusi Liadi 
vegetable crop; hence, awareness programs ought to be created for researchers, farmers and lay men.

Keywords: Amaranthus hybridus; Survey; Parasitic nematodes; Incidence; Population; Root gall.

\section{Introduction}

Green amaranth (Amaranthus hybridus L.) commonly known as Slim amaranth or Smooth pigweed, is a dicotyledonous plant belonging to the Family Amaranthaceae. The vegetable crop is an annual, that grows erect, with about 3 to 6 feet tall, unbranched or with branches occasionally, flower cluster spikes develop at top of central stem and from where leafstalk meet the stem, leaves alternate on stem and may have red tints along edges, long leafstalks, underside of each leaf has raised pinnate (feather-like), parallel veins, leaves are ovate to elliptic to lance shaped, and with a stem that is stout and longitudinally grooved or ribbed (Carrnel, 2012).

However, A. hybridus contain large amount of squalene, a compound that has both health and industrial benefits (Dubowitz, 2008). Despite the use of this plant for such purposes, there is little information on the nutritional and chemical composition of $A$. hybridus leaves. It possesses some medicinal properties to include Astringent, Hemostatic, Antidiarrheal, Nutritive, Alterative, Diuretic, Alkalizing, Anthelmintic (He and Corke, 2003; Carnel, 2012). The leaves, flowers and seeds (usually just leaves) are crushed and used together can also be use to cure acid stomach, snake bites, diarrhea and dysentery (Jansen van Rensburg et al., 2007). In Nigeria, $A$. hybridus leaves combined with condiments that are used to prepare soup or the leaves eaten as spinach or green vegetables.

Nematodes are worm-shaped nearly microscopic animals that are virtually invisible to the unaided eye when in soil or within plant material. Of the known nematodes species, approximately 50\%, $25 \%, 15 \%$, and $10 \%$ are free living, marine, animal parasites, and plant parasitic nematodes respectively (Niles and McIntyre, 1997).

Plant parasitic nematodes (PPNs) posses a spear-like structure, called a stylet, which is distinct in most, are forced into the plant cells and enzymes are injected to decompose the cell content.

Plant parasitic nematodes have been a great worry, as they cause about 20$60 \%$ yield loss to farmers. They affect the leave foliage and cause stem and root galls, stunted root of plant, discoloration, and perforation of leaves and also are responsible for weak stem, these leads to poor yield of plant, which in turn increases the cost of production (Perry et al., 2009).

The free-living nematodes are very important in maintaining the soil biodynamic system, especially in soil with low organic matter content, whereas PPNs feed on plants and reduce crop growth and yield efficiency. Eggs laid in the root or surrounding soil by the PPN females and hatch to produce worm-like larvae that usually go through four molts to reach maturity (Pokharel and Larsen, 2008). Only few PPNs genera or species feed on aerial plant parts, while the majority of PPNs feed on underground plant parts such as roots, bulbs, and tubers (Babatola and Omotade, 1990; Agbenin et al., 2004).

Other nematodes such as the root lesion nematode burrow into the root, feeding and causing damage through the plant roots (Mitkowski and Abawi, 2011). But, when infected, plants and roots die in the autumn, root lesion nematode will move out of the roots into the soil (Perry et al., 2009).

Green amaranth is one of the most important versatile vegetable consume in Nigeria, most especially in the northern part of the country, where the climatic conditions favor the cultivation and harvest of the plant, which in turn suffers great deal from plant parasitic and other under ground 
worms that may cause complete or total damage of the plant.

Conversely, poor crop nutrition, crop management, soil health status, and disease infections also may predispose plants to cold injury and nematode damage which might lead to great lost of production cost to the farmers.

PPNs may be endoparasitic; remaining and feeding inside cell, semiendo or semiectoparasitic; body half inside and half outside the plant surface, and/or ectoparasitic; remaining and feeding outside the plant cell (Perry et al., 2009). Root lesion nematodes cause small scratchlike lesions on feeder roots providing an avenue for other root rotting organism to infect (Mitkowski and Abawi, 2011).

Parasitic nematodes alone or in combination with other factors reduce crop productivity and they cause farmers and nurserymen thousands of naira in crop loss annually (Pokharel et al., 2009).

This research was carried out to investigate and determine the incidence and population of plant parasitic nematodes in infested green amaranth (Amaranthus hybridus) from the three selected farms in Dutsin-Ma, Katsina State Nigeria.

\section{Materials and methods}

\section{Study area}

The study was carried out in Dutsin-Ma Local Government Area (LGA), Katsina State, Nigeria. The LGA has an area of $527 \mathrm{~km}^{2}$ and a population of 169,671 at the 2006 census (NIPOST, 2009). The inhabitants of the Local Government are predominantly Hausa and Fulani by tribe. Their main occupation is farming and animal rearing (KSHD, 2013). Total annual rainfall around Dutsin-Ma is about $800 \mathrm{~mm}$. The inhabitants of the Local Government Area are predominantly Hausa and Fulani by tribe, with their main occupations as subsistence and irrigational farming and animal rearing.

\section{Collection site}

A survey of infested Green Amaranth plants was conducted within three selected farms; namely: Farm 1, 2 and
3, respectively. The Amaranthus hybridus farms were purposively selected within Dutsin-Ma Town, where irrigation system of farming on many vegetable crops is practiced. The criteria for selection of the farms to sample were based on accessibility of infestation of the plants, availability of farmer or escort, and the willingness of the farmers to allow sample collection from their farms.

\section{samples}

Collection of root and soil

Soil samples were taken from the rhizosphere of plants by digging a hole near the base of the roots $3 \mathrm{~cm}$ to $6 \mathrm{~cm}$ deep depending upon the plant size. Soil and root samples were collected randomly from plants showing symptoms of retarded growth. $500 \mathrm{~g}$ of soil sample was taken from each plant and kept in polyethylene bag, following Byrd et al. (1996) methods. Plant together with the root samples were placed in separate polyethylene bags, sealed tightly and labeled with details of host, locality and date of collection. A total of two hundred and forty (240) soil and root samples were collected.

\section{Nematode extraction}

Nematodes in soil were extracted in an aliquot of $500 \mathrm{~g}$ soil by sieving and decanting method (Byrd et al., 1996). The extracted nematodes were counted in counting chambers and identified under compound microscope (Labomed L x 300 LED Series). Identification of the specimens was performed according to morphological and morphometric characteristics as shown by Korayem et al. (2014).

\section{nematodes \\ Killing, fixing and processing of}

Nematodes were killed by gentle heat in an oven at $65-70^{\circ} \mathrm{C}$. Care was taken to avoid overheating. Specimens were immediately fixed for $24 \mathrm{~h}$ in TAF (Triethanolamine $40 \% 2 \mathrm{~mL}$, formalin $7 \mathrm{~mL}$ and distilled water were transferred in few $\mathrm{mL}$ of $1.25 \%$ glycerine solution containing traces of picric acid. The cavity 
block was placed in an incubator at $55^{\circ} \mathrm{C}$ for 4-5 days, described by Begum (1995).

\section{Temporary slide mounts}

For qualitative analysis, observation was made on temporary mounts with the use of compound microscope. Three small drops of concentrated nematode suspension were transferred on 3 x 1 glass slides, confined with a cover slip and sealed with zut (Begum, 1995).

\section{Analysis of data}

Data collected were subjected to analysis of variance (ANOVA) using package. The differences in the mean were partitioned using Duncan's multiple test range. Chi square $\left(\mathrm{X}^{2}\right)$ was also used to analyze data in each farm surveyed.

\section{Result}

The incidence and widespread distribution of plant parasitic nematodes among the three farms surveyed for soil root samples (Table 1). More frequent among the farmlands are species of the genera Meloidogyne, Heterodera, Paratrichodorus, Xiphinema, Pratylenchus, Tylenchorhychus, Helicotylenchus, and Aphelenchoides, but with Longidorus (7.08\%) having least frequency as indicted in Table 1.

Table 1. Occurrence of plant parasitic nematodes in three farms of A. hybridus.

\begin{tabular}{lccccc}
\hline PPNs & Farm 1 & Farm 2 & Farm 3 & $\begin{array}{c}\text { Total Number of } \\
\text { samples (240) }\end{array}$ & $\begin{array}{c}\text { General frequency } \\
\text { of occurrence (\%) }\end{array}$ \\
\hline Aphelenchoides & 15 & 7 & - & 22 & 9.16 \\
Helicotylenchus & 10 & - & 10 & 20 & 8.33 \\
Heterodera & 14 & 6 & 6 & 26 & 10.83 \\
Longidorus & - & 17 & - & 17 & 7.08 \\
Meloidogyne & 26 & 16 & 14 & 56 & 23.33 \\
Paratrichodorus & 13 & 13 & - & 26 & 10.83 \\
Pratylenchus & - & 14 & 18 & 32 & 13.33 \\
Tylenchorhychus & - & 6 & 13 & 19 & 7.92 \\
Xiphinema & 15 & 20 & - & 35 & 14.58 \\
\hline
\end{tabular}

However, Table 2 indicated the total number (population) of plant parasitic nematodes in all the 3 selected farms. It could be seen that Farm 2 has the highest population of parasitic nematodes, followed by Farm 1 and then Farm 3 (Table 2). The population gave a total number of 253 parasites discovered during the analysis. The presence of these parasitic nematodes was presented in Figures 4-8, but the most abundant was the Meloidogyne (Figure 7) in which all the parasites discovered appeared morphologically as thread-like and non-segmented.

Table 3 shows the incidence of plant parasitic nematodes in farm 1 , six nematodes were discovered with Meloidogyne been the most abundant, followed by Xiphinema, Aphelenchoides,
Heterodera, Paratrichodorus and Helicotylenchus.

Eight plant parasitic nematodes were extracted in Farm 2, Xiphinema, is the most abundance, with least population of Longidorus, Meloidogyne, Pratylenchus, and Paratrichodorus. Others with low frequency of occurrence include Tylenchorhychus, Heterodera, and Aphelenchoides as indicated in Table 4.

The presence plant parasitic nematodes extracted from the soil root samples in Farm 3 is shown in Table 5. Five parasitic nematodes were extracted. Paratrichodorus shows the highest incidence with Meloidogyne, Tylenchorhychus, Helicotylenchus, but species of the genera Heterodera are present in low percentages. 
Table 2. Plant parasitic nematodes extracted from three farms of A. hybridus.

\begin{tabular}{|c|c|c|c|}
\hline Farms & PPN Species & Population of PPNs & Total No. of PPNs \\
\hline \multirow[t]{9}{*}{1} & Aphelenchoides & 15 & \\
\hline & Helicotylenchus & 10 & \\
\hline & Heterodera & 14 & \\
\hline & Longidorus & - & \\
\hline & Meloidogyne & 26 & \\
\hline & Paratrichodorus & 13 & \\
\hline & Pratylenchus & - & \\
\hline & Tylenchorhychus & - & \\
\hline & Xiphinema & 15 & 93 \\
\hline \multirow[t]{9}{*}{2} & Aphelenchoides & 7 & \\
\hline & Helicotylenchus & - & \\
\hline & Heterodera & 6 & \\
\hline & Longidorus & 17 & \\
\hline & Meloidogyne & 16 & \\
\hline & Paratrichodorus & 13 & \\
\hline & Pratylenchus & 14 & \\
\hline & Tylenchorhychus & 6 & \\
\hline & Xiphinema & 20 & 99 \\
\hline \multirow[t]{9}{*}{3} & Aphelenchoides & - & \\
\hline & Helicotylenchus & 10 & \\
\hline & Heterodera & 6 & \\
\hline & Longidorus & - & \\
\hline & Meloidogyne & 14 & \\
\hline & Paratrichodorus & - & \\
\hline & Pratylenchus & 18 & \\
\hline & Tylenchorhychus & 13 & \\
\hline & Xiphinema & - & 61 \\
\hline Total & & 253 & 253 \\
\hline
\end{tabular}

PPNs = plant parasitic nematodes

- $\quad=$ no parasites

Table 3. Incidence of plant parasitic nematodes in Farm 1.

\begin{tabular}{|c|c|c|c|c|c|c|}
\hline PPN Species & Non infected & Infected & Incidence (\%) & Chi $\left(\mathrm{X}^{2}\right)$ & P value & DF \\
\hline Meloidogyne & 54 & 26 & 27.9 & & & \\
\hline Paratrichodorus & 67 & 13 & 13.9 & & & \\
\hline Logidorus & 0 & 0 & 0 & & & \\
\hline Xiphinema & 65 & 15 & 16.1 & 11.963 & 0.035 & 5 \\
\hline Pratylenchus & 0 & 0 & 0 & & & \\
\hline Tylenchorhynchus & 0 & 0 & 0 & & & \\
\hline Helicotylenchus & 70 & 10 & 10.8 & & & \\
\hline Heterodera & 66 & 14 & 15.1 & & & \\
\hline Aphelenchoides & 65 & 15 & 16.1 & & & \\
\hline Total & 387 & 93 & 100.0 & & & \\
\hline
\end{tabular}

PPN = plant parasitic nematode. 
Table 4. Incidence of plant parasitic nematodes in Farm 2.

\begin{tabular}{|c|c|c|c|c|c|c|}
\hline PPN Species & Non infected & Infected & Prevalence (\%) & Chi $\left(X^{2}\right)$ & P value & DF \\
\hline Meloidogyne & 64 & 16 & 16.2 & & & \\
\hline Paratrichodorus & 67 & 13 & 13.1 & & & \\
\hline Longidorus & 63 & 17 & 17.2 & & & \\
\hline Xiphinema & 60 & 20 & 20.2 & & & \\
\hline Pratylenchus & 66 & 14 & 14.1 & & & \\
\hline Tylenchorhynchus & 74 & 6 & 6.1 & & & \\
\hline Helicotylenchus & 0 & 0 & 0 & & & \\
\hline Heterodera & 74 & 6 & 6.1 & 19.69 & 0.0063 & 7 \\
\hline Aphelenchoides & 73 & 7 & 7.1 & & & \\
\hline Total & 541 & 99 & 100 & & & \\
\hline
\end{tabular}

PPN = plant parasitic nematodes.

Table 5. Incidence of Plant parasitic Nematodes in Farm 3.

\begin{tabular}{|c|c|c|c|c|c|c|}
\hline PPN Species & Non infected & Infected & Prevalence (\%) & Chi $\left(X^{2}\right)$ & P value & DF \\
\hline Meloidogyne & 66 & 14 & 22.9 & & & \\
\hline Paratrichodorus & 0 & 0 & 0 & & & \\
\hline Logidorus & 0 & 0 & 0 & & & \\
\hline Xiphinema & 0 & 0 & 0 & & & \\
\hline Pratylenchus & 62 & 18 & 29.5 & 7.81 & 0.098 & 4 \\
\hline Tylenchorhynchus & 67 & 13 & 21.3 & & & \\
\hline Helicotylenchus & 70 & 10 & 16.4 & & & \\
\hline Heterodera & 74 & 6 & 9.8 & & & \\
\hline Aphelenchoides & 0 & 0 & 0 & & & \\
\hline Total & 339 & 61 & 100 & & & \\
\hline
\end{tabular}

PPNs = plant parasitic nematodes

The Comparison of incidence of infection of nematode in the three farms is showed in Table 6, with Meloidogyne in Farm 1 having the highest incidences (27.9\%), Paratrichodorus (13.9\%), Longidorus in Farm 2 (17.2\%), Xiphinema (20.2\%), Pratylenchus in farm 3 (29.5\%), Tylenchorhyenchus (21.3\%), followed by Helicotylenchus (36.4\%). It could be deduced that, $A$. hybridus plants in Farm 1 that exhibited the least incidence was attacked by Aphelenchoides (16.1\%) and Heterodera (15.1\%) nematode parasites population. No significant difference ( $>0.05$ ) between the occurrence of the parasites and number of $A$. hybridus plants been infested.

Out of the 240 root samples, no severe galling was recorded, but 14 samples have moderate galling found in Farm 2, and Farm 1 possessed 7 and Farm 3 had 4 moderate roots galling. The mild galling damage was mostly recorded in Farm 2, where 33 samples were recorded, and 28 in Farm 1 and 12 in Farm 3. However, slight galling was recorded at 32 in Farm 3, 22 in Farm 1 and 12 in Farm 2. No galling occurred in 32 root samples in Farm 3, with Farm 2 having no galling in 21 root samples, and Farm 1 with 23 root samples indicated no galling. A section of infested A. hybridus plant (Figure 1) with most of the host plants been attacked by the nematode population. However, Figure 2 and 3 concurrently entailed the presence knots or galls and feeding disposition area of the parasitic nematodes. 
Table 6. Comparison of incidence and frequency of PPNs from the three selected farms.

\begin{tabular}{lccc}
\hline PPN Species & Farm 1 & Farm 2 & Farm 3 \\
\hline Meloidogyne & $27.9^{\mathrm{a}}$ & $16.2^{\mathrm{a}}$ & $22 . .^{\mathrm{a}}$ \\
Paratrichodorus & $13.9^{\mathrm{b}}$ & $13.1^{\mathrm{b}}$ & $0^{\mathrm{b}}$ \\
Logidorus & $0^{\mathrm{c}}$ & $17.2^{\mathrm{c}}$ & $0^{\mathrm{c}}$ \\
Xiphinema & $16.1^{\mathrm{d}}$ & $20.2^{\mathrm{d}}$ & $0^{\mathrm{d}}$ \\
Pratylenchus & $0^{\mathrm{e}}$ & $14.1^{\mathrm{e}}$ & $29.5^{\mathrm{e}}$ \\
Tylenchorhynchus & $0^{\mathrm{f}}$ & $6.1^{\mathrm{f}}$ & $21.3^{\mathrm{f}}$ \\
Helicotylenchus & $10.8^{\mathrm{g}}$ & $0^{\mathrm{g}}$ & $36.4^{\mathrm{g}}$ \\
Heterodera & $15.1^{\mathrm{h}}$ & $6.1^{\mathrm{h}}$ & $9.8^{\mathrm{h}}$ \\
Aphelenchoides & $16.1^{\mathrm{i}}$ & $7.1^{\mathrm{i}}$ & $0^{\mathrm{i}}$ \\
\hline
\end{tabular}

Letter of the same alphabet in the same row are not significant $(\mathrm{P}>0.05) . \mathrm{F}=0.12, \mathrm{P}=0.8803$. PPNs = plant parasitic nematodes.

PPN = plant parasitic nematodes.

Table 7. Incidence on root galling in the three farms.

\begin{tabular}{lccccc}
\hline Sites (farms) & $\begin{array}{c}\text { No galling } \\
\text { damage (1) }\end{array}$ & $\begin{array}{c}\text { Slight galling } \\
\text { damage (2) }\end{array}$ & $\begin{array}{c}\text { Mild galling } \\
\text { damage (3) }\end{array}$ & $\begin{array}{c}\text { Moderate galling } \\
\text { damage (4) }\end{array}$ & $\begin{array}{c}\text { Severe-root } \\
\text { galling (5) }\end{array}$ \\
\hline Farm 1 & $23^{\mathrm{a}}$ & $22^{\mathrm{a}}$ & $28^{\mathrm{a}}$ & $7^{\mathrm{a}}$ & $0^{\mathrm{a}}$ \\
Farm 2 & $21^{\mathrm{b}}$ & $12^{\mathrm{b}}$ & $33^{\mathrm{b}}$ & $14^{\mathrm{b}}$ & $0^{\mathrm{b}}$ \\
Farm 3 & $32^{\mathrm{c}}$ & $32^{\mathrm{c}}$ & $12^{\mathrm{c}}$ & $4^{\mathrm{c}}$ & $0^{\mathrm{c}}$ \\
\hline
\end{tabular}

Letter of the same alphabet in the rows are not significant $(\mathrm{P}>0.05) . \mathrm{F}=2.667, \mathrm{P}=0.1189$.

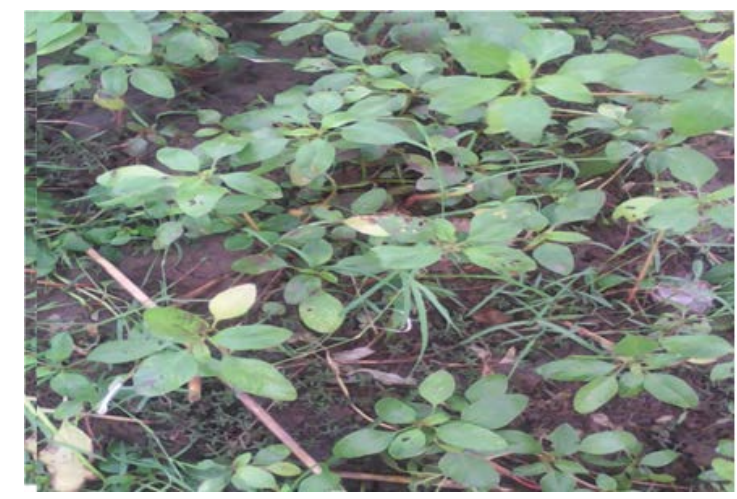

Figure 1. Poor yield of infested green amaranth in Farm 2.

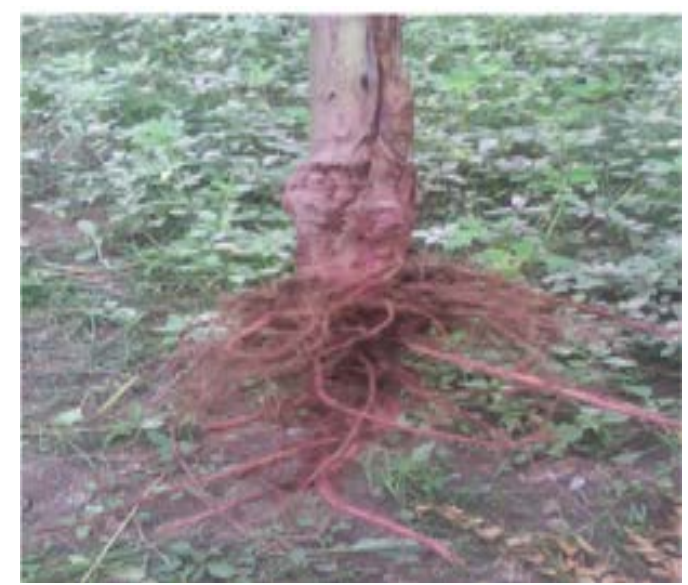

Figure 2. Sampled Root of A. hybridus containing galls. 


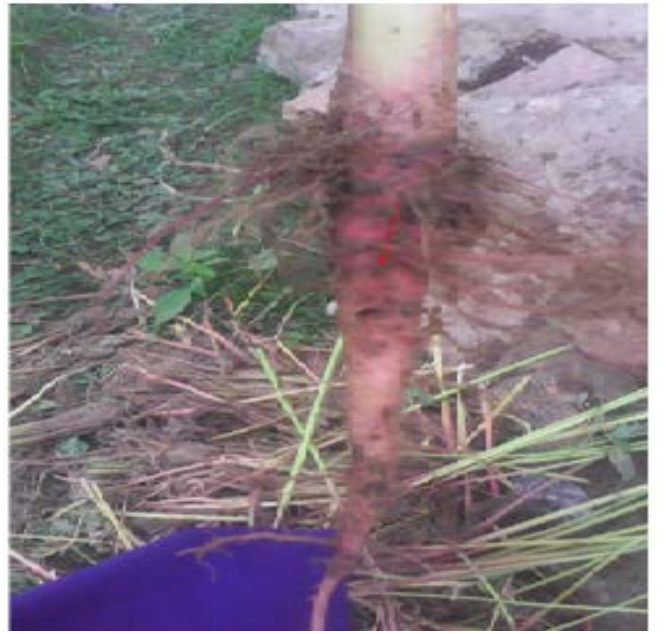

Figure 3. Sampled root with feeding disposition and portal entry of the parasitic nematodes

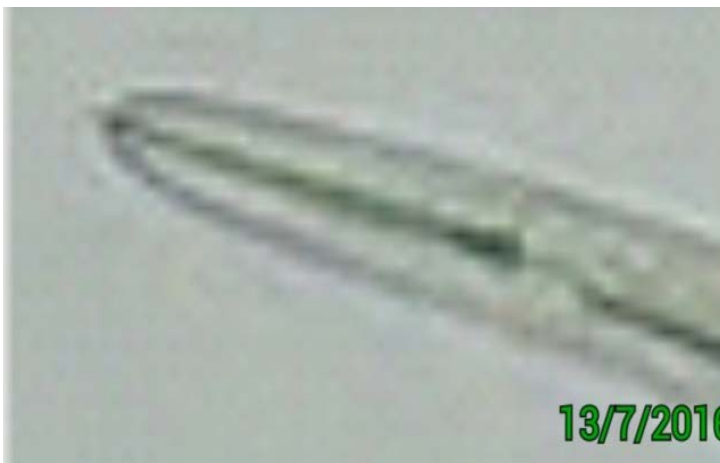

Figure 5. Xiphinema.

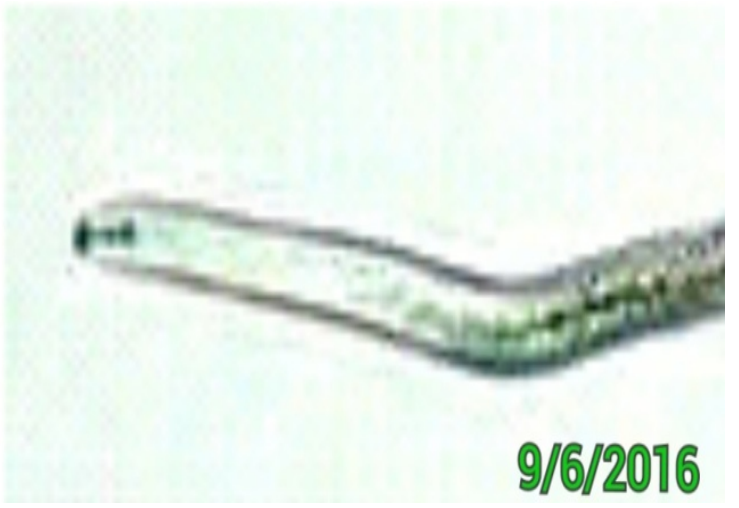

Figure 4. Pratylenchus.

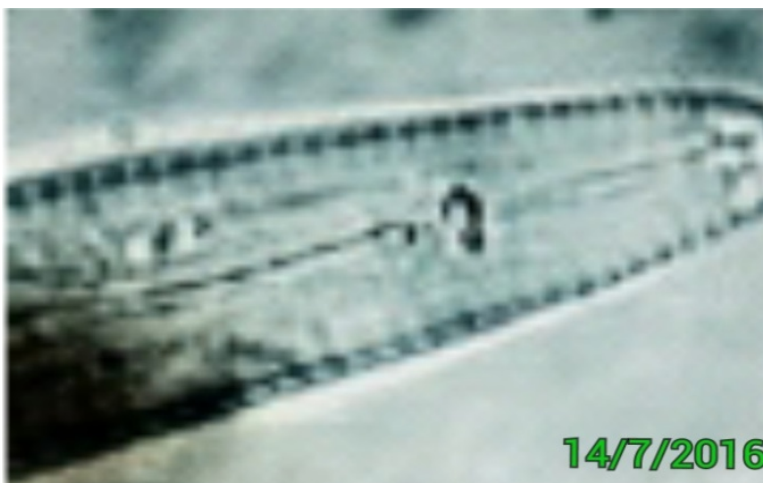

Figure 6. Tylenchorhychus.

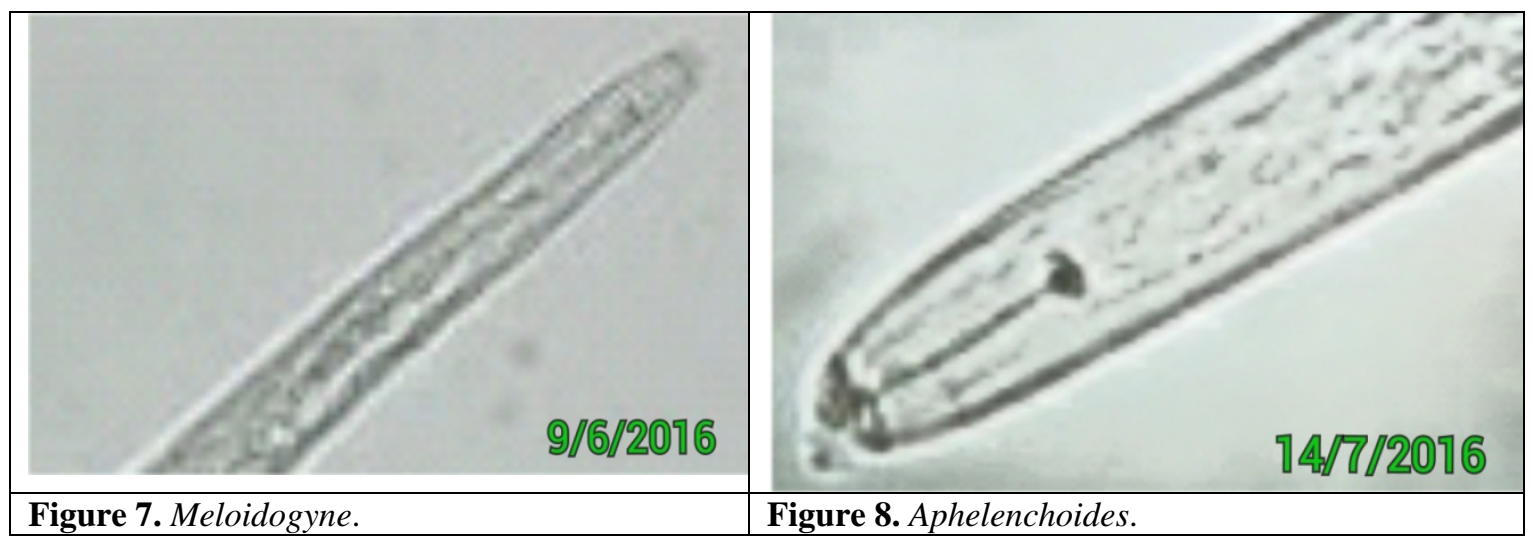

\section{Discussion}

It has been established in this research that green amaranth (A. hybridus) is one of the major vegetable crops grown in the study area. The plants surveyed during the study were mostly infested and found to be associated with poor and unhealthy growth. This might be attributed to the presence and susceptibility of 
A. hybridus by the plant parasitic nematodes revealed in this research. Traunfold (1998) reported that soil borne nematodes are plant parasites that can retard plant growth and diminish yields. He added that affected plants produce fewer and smaller fruit; where symptoms spread through a site as the season progresses through succeeding generations of juveniles hatch out.

It was revealed in this research that fewer A. hybridus plants rarely die prematurely from nematode feeding. This was initiated from the soil as nematodes might reproduce even in less sterilized soils. Kandji et al. (2001) reported that, the role nematodes play in limiting vegetable production depends to a large extent on the farming system employed and on the physical and/or chemical environment in the soil and on climate. Popovici and Ciobanu (2000) reported that the strength of the relationship between nematode community and soil type varies with the nematode species and that nematode reproduction is positively correlated with relative humidity and negatively correlated with air temperature. Also, they observed that soil texture is the most important factor explaining the presence of some nematode species and that environmental factor affect the ability of nematodes to parasitize and reproduce on their host.

This research also assessed the soils differing in texture and chemical composition which demonstrated the influence of soil physical and chemical properties on nematode population, distribution and fermented structure due to the decomposition of the organic particles following extraction. This validates the potential of nematodes as bio-indicator organisms of soil status (Kandji et al., 2001).

The microscopic examination of the root samples in this study clarified the presence of 9 genera of plant parasitic nematodes. The species include: Meloidogyne Xiphinema, Pratylenchus, Heterodera, Paratrichodorus, Aphelenchoides, Helicotylenchus, Tylenchorhychus and Longidorus. Among all, Meloidogyne was the most abundance in occurrence. This might be due to the less nutrient composition of the soil type, weather fluctuation, which may in turn favor the active multiplication of these parasites. This report is in line with the work of Olabiyi (2004) who reported that Meloidogyne spp are beneficial members of their ecosystems, but some are economic parasites of plants. Meloidogyne spp ( $M$. hapla and $M$. chitwoodi) are parasites of many dicotyledonous plants (Yusuf et al., 2006). Some crops that may be severely damaged by plant parasitic nematodes are tomato, pepper, okra, watermelon, cantaloupe, onion, pumpkin, squash, sweet potato, sweet corn, carrot, eggplant, bean and pea (Olabiyi, 2004). But, Eisenback and Triantaphyllou (1991) noticed that vegetable crops grown in warm climates experience severe losses from root knot nematodes. They also reported that rootknot nematode damage results in poor growth, decline in quality and yield of the crop and reduced resistance to other stresses leading to total crop loss.

The research reported the parasitic nematodes extracted from the roots infested A. hybridus plants, but species belonging to the genera Meloidogyne among others where found to possess a piercing needle structure in their mouth parts, found penetrated (portal of entry) in the root cells of the plants. This structure might be responsible in sucking up cell contents of the green amaranth, A. hybridus. The nematode parasites reported in this research were however small, worm, thread-like, measured about 45 to 50 microns in diameter $(\mu \mathrm{dm})$ and about $1 \mathrm{~mm}$ long.

The presence of these characters reported in this study might serve as contributing factor that enable the nematode parasites to live mainly in soil in corporate with fungi, bacteria and other soil organisms and gain chance of hatching more eggs that may in turn contribute to attack and feed in the roots of the $A$. hybridus plants. These report agreed with the work of Karssen (2002) whose work had shown that Southern root-knot nematodes, (Meloidogyne incognita) are microscopic round worms of the Tylenchid family. Bawa et al. (2014) reported that 
gradual increase of nematode eggs at their $\mathrm{J} 2 \mathrm{~s}$ in the tomato plants yield poor flowering set-up, leading to loose nutrients, with knots formed on the roots region. They added that, it might be because of the hidden nature, their vermiform and morphological structure of needle-like stylets of which the nematode parasites use to protrude the plant root cells.

The gradual increase and population of parasitic nematodes in the sampled roots of $A$. hybridus collected revealed more root knots or galls in the plants, with corresponding decrease in flowers along with stunted growth. Bawa et al. (2014) claimed that the infected tomato plants usually wilt easily, and are not productive due to an increased galling and many a times infection is easy to identify because of the large swellings easily noted on the root portion of the plant. The result also agreed with the work of Tariq et al. (2007) who reported that the plant parasitic nematode (Heterodera sacchati) penetrates plant cell with stylet, by injecting the secretory proteins thereby stimulating changes within the parasitized cells; which in turn produce large galls throughout the root system of infected plants. Perry et al. (2009) added that, root-knot nematode females are globose and sedentary at maturity, ranging from 400 to $1000 \mu \mathrm{m}$, but the male ones are vermiform ranging from 1100 to $2000 \mu \mathrm{m}$ in length. Stirling et al., (1992) reported that root knot nematode establish a feeding site on the plant root and permanently remain at that location allowing the giant cell to produce large amounts of proteins which the nematode use to ingest.

It was reported in this research that Meloidogyne (27.9\%) had the highest incidence of occurrence and population. In this regard, most of the $A$. hybridus sampled plants were found to exhibit weak stemming with patches, yellowed leaves, and poor flowering. This weak and unhealthy growth of the plants was not determined but as result, it might be attributed to the presence of these plant parasitic nematodes extracted from the infested plants. This report correlates with the work of Bawa et al. (2014) who reported that tomato 'Roma king' cv inhabit poor flowering, stunted stems with dark linings and yellowed leaves with white patches due to root knot nematode $M$. incognita attack. But, Agbenin et al. (2004) estimated about 69\% drop in cowpea yield and Tariq et al. (2007) reported approximately $75 \%$ reduction in tomato yield because of this pathogen.

The presence of Aphelenchoides, Longidorus, Trichodorus and Xiphinema was also reported. Perforation on leafs and buds of the A. hybridus was established in this study, the incidence of this parasites was investigated, but its pathogenicity was not fully assessed or determined, but this could also aid the transmission of virus and bacteria in the plants surveyed. However, the parasitic nematodes examined and reported in this study might be responsible in facilitating the transmission of some plant viruses which cause some viral diseases thereby triggering the development of these parasitic nematodes.

Other plant parasitic nematodes discovered in the examined samples include: Helicotylenchus, Heterodera, Aphelenchoides, Tylenchorhynchus and Pratylenchus. A. hybridus plants attacked by these parasites exhibit chlorotic leaves, poor flowering, stunted stems and knots or galls on the roots. These nematodes feed on cell sap of infected plants causing damage to the plants. Their economic importance and amount of damage have not received the necessary attention. This study provides an update on the findings of Fisayo and Steven (2014), who worked on the distribution and occurrence of root-knot, dagger and lesion nematodes on pineapple. Anwar and McKenry (2010) reported Meloidogyne spp., in damaging root cells of vegetable crops.

The present research compares the presence of these nematode parasites, with no significance difference $(p>0.05)$ in most of the infested susceptible host plants. This could be explained by the fact that, the extracted parasites around the rhizosphere region are vulnerable and responsible for attacking the roots, thereby causing severe to moderate galling or knots. The presence of these root knots or galls might be 
responsible in weakening the stem and increased swollen galls in the $A$. hybridus plants. These reports correlates with the findings of Moqbel et al. (2006) who reported that 9 phytoparasitic nematode genera were found to be associated with vegetable crops soil samples. Meloidogyne spp. were the most common nematodes in carrot, common bean, potato, tomato, and watermelon soil samples with $11.1 \%-57.1 \%$ frequency of occurrence, and population densities ranged between 190-827 nematodes/250 g soil. They added that, in broad bean, carrot, summer squash and tomato soil samples, Tylenchorhynchus spp. were the most prevalent nematodes with $11.836 .4 \%$ frequency of occurrence, and population densities ranged between 330$1,190 \%$ nematodes/250 g soil. But, Agbenin et al. (2004) reported 100\% loss on leaves per tomato plants inoculated with 8,000 eggs and a $100 \%$ loss on fruit number and weight of fruits with a rapid increase in root galling up to 10,000 inoculums level of $M$. incognita ( $\mathrm{p}>0.05)$.

Yield reductions cannot be proven without studies using nematicides, soil fumigation or resistant and susceptible crop varieties. Under such situation, we assessed the losses caused by plant parasitic nematodes on our visual field observations, farmers' responses, and level of nematode infestation on versatile crop (green amaranth).

\section{Conclusion}

The results of the research confirmed the ubiquitous occurrence of plant parasitic nematodes, which as a result, caused serious yield reduction in Amaranthus hybridus. The study revealed a widespread distribution of plant parasitic nematodes, where the genus Meloidogyne had been confirmed to have the largest population with higher harmful potentiality in comparison with other nematode parasites in the studied area. Hence, population densities of all other nematode species were similar and significantly lower than that of Meloidogyne. The presence of these parasitic nematodes even at low populations in the soil is significant, as population build up could eventually result to reduction of crop yield.

\section{Acknowledgements}

We thank the Head of Department (Dr. A. S. Dankishiya) Biological Sciences, Federal University Dutsinma (FUDMA), for recommending the equipment used in this research. Special thank to Mr. Michael Udele (Chief Laboratory Technologist) FUDMA, for his kind cooperation in the practical analysis of the work.

\section{Conflicts of interest}

Authors declare that they have no conflict of interests.

\section{References}

Agbenin, N. O.; Emechebe, A. M.; Merly, P. S. Evaluation of neem powder for Fusarium wilt and Meloidogyne control on tomato. J. Lab. Ass. Phytopathology, v. 37, no. 4, p. 320-321, 2004.

Anwar, S. A.; Mckenry, M. C.; Javed, N. The root-knot nematodes: destructive pests of crops. Proceedings of International Symposium on Sustainable Crop Improvement and Integrated Management, Faisalabad, Pakistan, p. 216-222, 2006.

Babatola, J. O. Omotade, M. A. Chemical control of nematode pests of Cowpea. Journal of Crop Protection, v. 13, p. 131-132, 1990.

Bawa, J. A.; Bashir, K. A.; Mohammed, I. Pathogenicity study of Southern root knot nematodes (Meloidogyne incognita Chitwood) on Roma King Tomato Cultivar (CV). International Research Journal of Biological Sciences, v. 3, no. 11, p. 5-9, 2014.

Begum, Z. Survey and distribution of plant nematode associated with ornamental and vegetable crop in Pakistan. Biotropica, v. 30, p. 2342-2349, 1995.

Byrd, D. W.; Nusbaum, C. J.; Barker, K. R. A rapid flaotation - sieving technique for extracting nematodes from soil. Plant Disease Report, v. 50, p. 954-957, 1996.

Carrnel, D. Amaranthus hybridus (slim amaranth, female finger). Carrnell Dixon fact sheet. Survival Plants Memory Course, 2012. p. 289-292. 
Dubowitz, T.; Heron, M.; Bird, C. E.; Lurie, N.; Finch, B. K. Neighborhood socioeconomic status and fruit and vegetable intake among whites, blacks, and Mexican Americans in the United States. Am. J. Clin. Nut., v. 87, p. 18831891, 2008.

Eisenback, J. D.; Triantaphyllou, H. H. Rootknot Nematodes: Meloidogyne species and races. In: Nickle, W. R. (Ed.). Manual of Agricultural Nematology. New York: Marcel Dekker, 1991. p. 284-286.

Fisayo, D.; Steven, A. Studies on the distribution of plant-parasitic Nematodes associated with pineapple in Delta, Imo and Cross River States of Nigeria. Aus. J. Basic Appl. Sci., v. 8, no. 7, p. 248-256, 2014.

He, H. P.; Corke, H. Oil and squalene in Amaranthus grain and leaf. J. Agric. Food Chem., v. 51, no. 27, p. 7913-7920, 2003.

Jansen van Rensburg, W. S.; Van Averbeke, W.; Slabbert, R.; Faber, M.; Van Jaarsveld, P.; Van Heerden, I.; Wenhold, F.; Oelofse, A. African leafy vegetables in South Africa. Water SA, v. 33, no. 3, p. 317-326, 2007. Available from: <http://www.ajol.info/index.php/wsa/ article/view/49110/35456>. Accessed on: Sept. 14, 2016.

Kandji, S. T.; Callistus, K. P. O.; Albrecht, A. Diversity of plant-parasitic nematodes and their relationships with some soil physico-hemical characteristics in improved fallows in Western Kenya. Appl. S. Ecol., v. 18, p. 143-154, 2001.

Karssen, G. The plant-parasitic nematode genus Meloidogyne Goeldi, 1892 (Tylenchida) in Europe. Boston MA: Brill Academic Publishers, 2002.

Korayem, A. M.; Youssef, M. M. A.; Mohamed, M. M. M.; Lashein, A. M. S. A survey of plant parasitic Nematodes associated with different plants in North Sinai. Middle East Journal of Agriculture Research, v. 3, no. 3, p. 522-529, 2014. Available from: <http://www.curresweb.com/mejar/mejar/2014/ 522-529.pdf>. Accessed on: Sept. 14, 2016.

KSHD - Katsina State with History of DutsinMa; Dutsin-Ma LGA, 2013. p. 3-5.

Mitkowski, N. A.; Abawi, G. S. Root-knot nematodes. The Plant Health Instructor. The American Phytopathological Society, 2011. p. 89-91.

Mokbel, A. A.; Ibrahim, I. K. A.; El-Saedy, M. A. M.; Hammad, S. E. Plant parasitic nematodes associated with some fruit trees and vegetable crops in Northern Egypt. Egypt. J. Phytopathol., v. 34, no. 2, p. 43-51, 2006.

Niles, R. K.; McIntyre, G. A. Colorado plant pathogenic nematode survey 1996-1997. Fort Collins: Colorado State University, 1997.

NIPOST - Nigerian Post Office with map of LGA, 2009.

Olabiyi, T. I. Assessment of the nematoxic properties of the water extracts of four plants species on root knot nematode infection of Coelosia argentea (L.) Zuma. Plant Pathology Journal, v. 5, no. 2, p. 167-170, 2004.

Perry, R. N.; Moens, M.; Starr, F. J. (Eds.). Root-Knot Nematodes. Wallingford, UK: CAB International, 2009.

Pokharel, R. R.; Larsen, H. J. Plant parasitic nematodes associated with fruit crops in western Colorado. In: Godin, R. (Ed.). Western Colorado Research Center Annual Report 2007. Ft. Collins: Colorado State University, 2008.

Pokharel, R. R.; Larsen, H. J.; Hammon, B.; Gourd, T.; Bartolo, M. Plant parasitic nematodes, soil and root health in Colorado onion fields. In: Godin, R. (Ed.). Western Colorado Research Center, Colorado State University. Annual report. Ft. Collins: Colorado State University, 2009.

Popovici, I.; Ciobanu, M. Diversity and distribution of nematode communities in grasslands from Romania in relation to vegetation and soil characteristics. Appl. S. Ecol., v. 14, p. 27-36, 2000.

Stirling, G. R.; Stanton, J. M.; Marshalls, J. W. The importance of plant parasitic nematodes to Tropical Agriculture. Aust. Pl. Pathol. J., v. 21, p. 104-106, 1992.

Tariq, M.; Firoza, K.; Shahina, F. Medicinal plants as new hosts of root-knot and other nematodes from Hamdared University, Karachi, Pakistan. Pak. J. Nem., v. 25, p. 165-172, 2007. Traunfeld, J. Home and Garden Information Center. University Maryland Extension, 1998.

Yusuf, M. N.; Othman, D.; Nisir, B.; Haseeb, A. Toxicity of Plant latex to some plant parasitic nematodes. National Academy of Science News Letter, v. 7, p. 16-23, 2006. 
Braz. J. Biol. Sci., 2016, v. 3, no. 6, p. 319-330. 